\title{
Struktura argumentacje we wniosku formalnym na wybranym przykładzie
}

\section{The argumentation structure in formal inquiry choosen example}

\author{
Victoria Kamasa \\ INSTYTUT JĘZYKOZNAWSTWA, UNIWERSYTET IM. ADAMA MICKIEWICZA \\ AL. NiEPODLEGŁOŚCI 4, 61-874 POZNAŃ \\ VKAMASA@AMU.EDU.PL
}

\begin{abstract}
The aim of the paper is to reconstruct the argumentational structure of formal inquiry on chosen example. It also attempts to assess the validity of every identified part of argumentations. This assessment is done by the use of notions and methods postulated by Tokarz (2006) for formalization and judgment of argumentation. As a result, proposal of general structure of argumentation and structure of every subarguments used in analyzed text is presented.
\end{abstract}

\section{Cel}

Celem niniejszego tekstu jest opis struktury argumentacyjnej oficjalnego wniosku na przykładzie „Wniosku o przekształcenie Instytutu Filologii Angielskiej w podstawową jednostkę organizacyjną UAM”. Podstawowe pytanie badawcze brzmi zatem: Jak zbudowane są argumenty przytaczane przez autorkę wyżej wspomnianego wniosku na poparcie stawianej przez nią tezy. Dodatkowo podejmiemy także próbę oceny przedstawionej argumentacji. Tekst może posłużyć także jako przykład aplikacji proponowanej przez Tokarza (2006) procedury formalizacji i oceny argumentów we wniosku formalnym. 


\section{Podstawy metodologiczne}

\subsection{Przedmiot badań}

Przedmiotem analizy będzie „Wniosek o przekształcenie Instytutu Filologii Angielskiej w podstawową jednostkę organizacyjną UAM" datowany na 14 kwietnia 2011, skierowany do Rektora UAM prof. dr hab. Bronisława Marciniaka przez prof. dr hab. Katarzynę Dziubalską-Kołaczyk, dyrektora Instytutu Filologii Angielskiej UAM. W analizie uwzględnimy zarówno sam wniosek, wraz z zawartym w nim uzasadnieniem i opisem jednostki, oraz załączniki do tego wniosku w przypadku, jeśli tekst główny odsyła do takich załączników.

$\mathrm{Na}$ etapie wyboru przedmiotu badań możemy zapytać, czy wybrany wniosek stanowi w ogóle przykład argumentacji i czy tym samym może być dalej sensownie analizowany w poszukiwaniu odpowiedzi na postawione powyżej pytania badawcze. W przedstawionym tekście odnajdujemy terminologiczną wskazówkę, że tekst ten jest argumentacją w postaci nadania jednej z jego części tytułu „Uzasadnienie” (Blair, 1992, str. 367). $\mathrm{Na}$ argumentacyjny charakter tekstu wskazuje również sytuacja komunikacyjna, w której został on sformułowany, a więc sytuacja wnioskowania o coś do kogoś (Blair, 1992, str. 368). Przyjąć zatem możemy, że analizowany tekst stanowi przykład argumentacji.

\subsection{Metoda badań}

Dla odtworzenia struktury argumentów posłużymy się schematycznym sposobem zapisywania argumentów zaproponowanym przez Tokarza (Tokarz, 2006, strony 132 - 138). Zastosujemy zarówno podział na argumentację główną i wewnętrzną, jak i na argumenty szeregowe i równoległe. W przypadku wątpliwości dotyczących tego, czy argumenty wpierają tezę równolegle czy szeregowo, stosować będziemy kryterium zaproponowane przez Szymanka1: argumentację można uznać za szeregową, jeśli wykluczenie którejkolwiek z przesłanek zupełnie pozbawia pozostały zespół mocy uzasadniającej (2001, str. 41), innymi słowy: daną argumentację uznamy za równoległą, chyba że istnieją wyraźne i jednoznaczne przesłanki, by stwierdzić, że jest argumentacją szeregową. Jako podstawową i nadrzędną zasadę $\mathrm{w}$ rekonstrukcji argumentów przyjmiemy zasadę życzliwości $\mathrm{w}$ sformułowaniu proponowanym przez Goviera: Aby zrozumieć, jak ktoś argumentuje, staramy się odtworzyć linię myśli, która bylaby spójna i logiczna (Govier, 1987, str. 133). Zastosujemy również Generalne strategie formalizacji argumentacji zaproponowane również przez Goviera (2010, str. 31).

1 Stosuje on nieco inne terminy: argumentację równoległą określa jako „uzasadnienie rozdzielne”, zaś szeregową jako „uzasadnienie łączne". 


\subsubsection{Problem przesłanek ukrytych}

Jednym $\mathrm{z}$ istotnych problemów napotykanych podczas próby formalizacji argumentacji jest problem przesłanek ukrytych lub inaczej przesłanek entymematycznych: zarówno niektóre przesłanki, jak i wniosek nie musza pojawiać się explicite, a jedynie implicite, jako niewypowiedziane głośno, intencjonalne składniki wypowiedzi, których wykrycie nadawca pozostawia inteligencji odbiorcy (Tokarz, 2006, str. 134). Z kolei Szymanek definiuje przesłankę entymematyczną jako przesłankę pominiętą $\mathrm{w}$ entymemacie, a więc mającym być dedukcyjnym argumencie, $w$ którym pominięto przedstawienie jednej lub kilku przestanek, pozostawiając ich brzmienie domyślności odbiorcy (2001, str. 130). Problemem, jakiego nastręcza zastosowanie tych definicji w praktyce jest zakładana intencjonalność takich przesłanek - wydaje się, że by w pełni poprawnie zidentyfikować te przesłanki musielibyśmy móc zweryfikować, czy proponowane przez nas składniki argumentacji były faktycznie zamierzane przez jej twórcę. W przypadku analizowanego tutaj materiału jest to niemożliwe. $\mathrm{Na}$ ryzyko związane $\mathrm{z}$ dowolnym dopisywaniem takich przesłanek do argumentacji zwraca uwagę Govie: Jeśli zaczniemy dodawać przestanki za każdym razem, kiedy nie uznajemy logicznego ciągu argumentów za naturalny, skończymy odchodząc od argumentacji, od których analizy rozpoczęliśmy nasza pracę i badając nową argumentację, którą sami stworzyliśmy (2010, str. 44).

Ze względu na to właśnie ryzyko cytowany autor sugeruje daleko idącą ostrożność w dodawaniu przesłanek do argumentacji, zalecając to jedynie w przypadku, gdy spełnione są następujące warunki:

1 Sformułowanie tekstu dostarcza dobrego powodu, by to uczynić; LUB

2 Przesłanka ta jest konieczna, aby argumentacja była spójna; I RÓWNOCZEŚNIE

3 Argumentujący zaakceptowałby tę przesłankę,

a także wskazuje na rolę uzasadnienia dodania tej przesłanki formułowanego przez analizującego argumentację (Govier, 2010, strony 44 - 45). Z tych względów postaramy się zachować ostrożność w uzupełnianiu argumentacji o przesłanki ukryte, zaś każdy taki zabieg uzasadnimy powołując się na sam tekst lub jego kontekst.

\subsubsection{Ocena argumentacji}

Dla oceny poszczególnych argumentów weźmiemy pod uwagę zarówno stopień akceptowalności poszczególnych przesłanek, jak i siłę inferencji między przesłankami a wnioskiem (Tokarz, 2006, str. 142). Obie te zmienne ${ }^{2}$ oraz ogólny stopień akceptowalności poszczególnych subtez oraz

2 Dla przesłanki: 1 - nie jest możliwe, aby sąd P był prawdziwy, 2 - jest bardzo prawdopodobne, że sąd P jest fałszywy, 3 - wartość logiczna sądu P jest nierozstrzygalna, 4 - jest bardzo prawdopodobne, że sąd P jest prawdziwy, 5 - jest pewne, że sąd $\mathrm{P}$ jest prawdziwy. Dla inferencji: 1 - T nie ma logicznego związku z P, 2 - sytuacja, w której P jest prawdą, zaś T fałszem jest bardzo prawdopodobna, 3 - nie 
tezy głównej oszacujemy według skali zaproponowanej przez Tokarza (2006, strony 142 - 146). Przy ocenie siły inferencji odwołamy się również do pojęcia pozytywnej istotności (positive relevance) $\mathrm{w}$ rozumieniu proponowanym przez Goviera: Twierdzenia A jest pozytywnie istotne dla innego twierdzenia $B$, wtedy $i$ tylko wtedy, gdy prawdziwość $A$ przyczynia się do uznania prawdziwości A. Oznacza to, że A dostarcza pewnych dowodów lub pewnych powodów, by wierzyć $w$ B (Govier, 2010, str. 148). Poszczególne oceny zostaną krótko uzasadnione.

Dla każdej subargumentacji najpierw ocenimy wszystkie te twierdzenia w niej zawarte, które nie są już uzasadniane przez inne twierdzenia, następnie zaś zgodnie z regułami zaproponowanymi przez Tokarza obliczymy stopnie akceptowalności wszystkich konkluzji wewnętrznych służących jako przesłanki dalszych argumentów, aż do momentu, kiedy stanie się możliwa ocena głównej tezy danej subargumetnacji (Tokarz, 2006, str. 148), by na końcu ocenić stopień akceptowalności głównej tezy.

Ze względu na w pewnym stopniu subiektywny charakter oceny zarówno tez jak i siły inferencji oraz inne czynniki wskazane przez Tokarza istotne jest zachowanie daleko idącej ostrożności w interpretacji wyników przedstawionej tu oceny, zgodnie z prezentowaną przez cytowanego autora zasadą, że: (a) to, iż teza jest akceptowalna, nie znaczy, że jest ona prawdziwa; (b) to, iż teza nie jest akceptowalna, nie znaczy, że jest ona fałszywa (Tokarz, 2006, str. 147). Taka ostrożność ma w tym przypadku dodatkowe uzasadnienie w celu prowadzonej tutaj analizy, którym jest jedynie opis stosowanej argumentacji i jej siły, nie zaś weryfikacja słuszności dowodzonej tezy.

\subsection{Notacja}

Zastosujemy następującą konwencję zapisu:

- Dokładne cytaty z analizowanego tekstu podane zostaną kursywą wraz z oznaczeniem miejsca, z którego pochodzą: W - część wstępna, U uzasadnienie, OI - opis jednostki, $\mathrm{P}$ - podsumowanie, $\mathrm{Z}$ - załączniki.

- Użyjemy następujących skrótów: IFA - Instytut Filologii Angielskiej, WN - Wydział Neofilologii, WA - Wydział Anglistyki oraz innych powszechnie przyjętych w społeczności akademickiej skrótów.

- Argumentowana teza zapisana będzie po prawej stronie, zaś wspierające je przesłanki zapiszemy po jej lewej stronie, zaś przesłanki je wspierające z kolei po ich lewej stronie etc.

- Argumenty, które uznamy za równoległe obwiedzione zostaną linią ciągłą.

- Poszczególne elementy argumentacji szeregowej obwiedzione zostaną linią przerywaną i opatrzone na końcu znakiem „+”.

- Stopień akceptowalności twierdzenia X oznaczymy jako A(X).

- Siłę przejścia między twierdzeniami X i Y oznaczymy jako S(X/Y).

da się stwierdzić, czy P uzasadnia T mocno, czy słabo, 4 - sytuacja, w której P jest prawdą, a T fałszem jest mało prawdopodobna, 5 - T wynika dedukcyjnie z P (Tokarz, 2006, str. 143) lub P jednoznacznie wskazuje zachodzenie T. 


\section{Identyfikacja tezy}

Teza nie jest jednoznacznie identyfikowalna. Wydaje się, że w analizowanym tekście znajdują się trzy sformułowania, które można uznać, za główną tezę argumentacji. Jedno z nich pojawia się na początku, zaś dwa pozostałe na końcu tekstu:

Zwracam się do Pana Rektora z prośba o wystapienie do Senatu UAM z wnioskiem o przeksztatcenie Instytutu Filologii Angielskiej na Wydziale Neofilologii UAM $w$ Wydziat (W)

Instytut Filologii Angielskiej spetnia zarówno ustawowe i statutowe jak $i$ inne merytoryczne wymogi stawiane przed podstawowa jednostka uniwersytetu $(P)$

Wydziat Anglistyki stanowitby wzbogacająca nowa jakość dla Uniwersytetu im. Adama Mickiewicza w Poznaniu (P).

$\mathrm{Na}$ sformułowania (2) i (3) jako tezy prowadzonej argumentacji wskazuje sama autorka tekstu wprowadzając je frazą $\mathrm{Na}$ podstawie powyższej argumentacji ośmielam się podsumować (P), która sugeruje jak się wydaje, że stwierdzenia te stanowią podsumowanie całej argumentacji, tym samym są jej tezami.

Jednak sama struktura dokumentu wydaje się przemawiać za uznaniem pierwszej z przedstawionych propozycji za podstawową tezę tekstu z następujących powodów:

1. Analizowana poniżej argumentacja przedstawiona jest jako „uzasadnienie” wyżej wymienionej prośby;

2. Dwie pozostałe tezy występują wśród argumentów wspierających tezę we fragmencie oznaczonym jako „uzasadnienie”.

$Z$ tej przyczyny za tezę uznane zostaje sformułowanie: „Dobrze jest przekształcić IFA na WA”. Uzasadnienia takiej parafrazy można szukać np. w teorii aktów mowy w wersji Searle’a. Cytowana wyżej wypowiedź zawiera wyraźnie performatywne wyrażenie zwracam się (...) z prośba, zgodnie zaś z jednym z warunków fortunności sformułowanych przez Searle’a dla tego aktu mowy, prośba oznacza, że nadawca chce aby odbiorca wykonał czynność stanowiącą przedmiot prośby (Searle 1987, 77-90).

\section{Struktura argumentacji}

\subsection{Argumenty bezpośrednio wspierające główną tezę}

Zgodnie z przeprowadzoną powyżej analizą główną tezą analizowanej argumentacji będzie:

(T) Dobrze jest przekształcić IFA na WA.

W tekście „Uzasadnienia” odnaleźć możemy następujące argumenty wspierające tę tezę:

(1) IFA spełnia wszystkie wymagania stawiane podstawowym jednostkom organizacyjnym (Już $w$ chwili obecnej Instytut Filologii Angielskiej spetnia wszystkie ustawowe i statutowe wymagania stawiane wobec podstawowych jednostek organizacyjnych szkót wyższych (U)). 
(2) IFA posiada potencjał jako przyszła podstawowa jednostka organizacyjna (Dotychczasowa działalność Instytutu Filologii Angielskiej dokumentuje jego wybitne osiągnięcia $w$ realizacji zadań naukowych $i$ dydaktycznych oraz wskazuje na jego potencjat jako przyszłej podstawowej jednostki Uniwersytetu, która już obecnie posiada wiele cech wydziatu. (U)).

(3) IFA posiada obecnie wiele cech wydziału (jego [IFA] potencjat jako przyszłej podstawowej jednostki Uniwersytetu, która już obecnie posiada wiele cech wydziatu. (U)).

(4) Potencjał IFA już obecnie rozwija się dynamicznie (Wniosek o przeksztatcenie IFA $w$ Wydziat uzasadniony jest dynamicznym rozwojem jego potencjału naukowego i dydaktyczno-organizacyjnego w ostatnich latach (U)).

(5) Otwarcie WA będzie korzystne dla UAM (przesłanka nie wyrażona explicite).

Wszystkie powyższe argumenty wspierają tezę równolegle, zatem schemat argumentacji wygląda następująco:

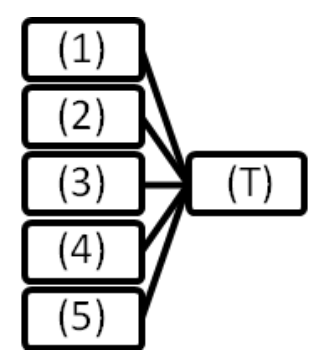

Rys. 4.1.

\subsection{Subargumentacja dla argumentu (1)}

W powyższym schemacie pierwszym $\mathrm{z}$ argumentów jest spełnianie przez IFA wszystkich kryteriów stawianych podstawowym jednostkom organizacyjnym (1). W analizowanym tekście przedstawiono także liczne przesłanki popierające tę tezę, zarówno bezpośrednio, jak i pośrednio:

(6) IFA ma uprawnienia do nadawania stopnia doktora i doktora habilitowanego (Od niemal 10 lat Instytut posiada uprawnienia do nadawania stopnia doktora i doktora habilitowanego (U)).

(7) IFA prowadzi studium doktoranckie (Od niemal 10 lat Instytut (...) prowadzi własne prężnie działające, niezależne od wydziału Studium Doktoranckie (U)).

(8) IFA posiada odpowiednią kadrę (Instytut dysponuje odpowiednia jakościowo i ilościowo kadra naukowo-dydaktyczna (U)).

(9) IFA prowadzi własny kierunek studiów (Instytut (...) prowadzi własny kierunek studiów filologia angielska (jak też kilka specjalności w ramach kierunku filologia) (U)).

(10) Dane liczbowe związane $\mathrm{z}$ działalnością studium doktoranckiego (Na mocy powyższych uprawnień, $w$ okresie od grudnia 2002 roku do chwili obecnej, nadano $w$ Instytucie 96 stopni doktora $w$ tym: 78 
dr Victoria Kamasa: Struktura argumentacji we wniosku formalnym...

$w$ zakresie językoznawstwa, $18 w$ zakresie literaturoznawstwa (OI) oraz Instytutowe Studium Doktoranckie ksztatci obecnie 83 doktorantów, $w$ tym 49 studentów stacjonarnych (ze stypendium) $i$ 34 niestacjonarnych. W tej chwili otwartych jest 58 przewodów doktorskich, $w$ tym 30 osób niebędących $w$ tej chwili studentami doktoranckimi (2 pracowników, 13 osób z ukończonymi w IFA studiami doktoranckimi, 15 osób spoza IFA). Łącznie zatem 113 osób pracuje nad doktoratem (OI)).

(11) Dane liczbowe dotyczące pracowników IFA (Obecnie $w$ IFA zatrudnionych jest $w$ petnym wymiarze czasu pracy:12 profesorów tytularnych, 16 doktorów habilitowanych, 68 doktorów. W skład kadry IFA wchodzi także 83 doktorantów (OI)).

(12) Pracownicy IFA biorą udział we władzach UAM, komisjach przy UAM oraz Radzie Narodowego Programu Rozwoju Humanistyki (Znaczacy i nobilitujacy jest udziat pracowników IFA we władzach UAM (...). W minionych latach pracownicy IFA reprezentowali Wydział Neofilologii $w$ Senacie UAM oraz kilkakrotnie byli członkami wtadz dziekańskich. Obecnie pracownicy IFA petnia funkcje: prorektora UAM (prof. $d r$ hab. Jacek Witkoś) $i$ prodziekana Wydziatu Neofilologii (prof. dr hab. Piotr Gasiorowski). Ponadto Dyrektor IFA, prof. dr hab. Katarzyna Dziubalska-Kołaczyk, bierze aktywny udziat $w$ tworzeniu Strategii UAM oraz $w$ pracach mających na celu udoskonalenie zarzadzania uczelnia, najpierw będac cztonkiem powotanych przez JM Rektora UAM Zespole ds. Opracowania Projektu Strategii Rozwoju Uniwersytetu, a obecnie $w$ Zespole ds. Oceny Wdrażania Strategii Rozwoju UAM oraz w Zespole ds. Przygotowania Projektu Optymalizacji Zarządzania UAM. Ponadto 24 stycznia 2011 prof. Barbara Kudrycka, minister nauki $i$ szkolnictwa wyższego, powołała prof. Katarzynę DziubalskaKołaczyk $w$ skład Zespotu Doradczego - Rady Narodowego Programu Rozwoju Humanistyki.(OI)).

Dodatkowo zasadne wydaje się dodanie ukrytej przesłanki:

(13) Nadawanie stopnia dr i dr hab., prowadzenie własnego studium doktoranckiego, posiadania kadry na odpowiednim poziomie oraz prowadzenie własnego kierunku są warunkami stawianymi podstawowym jednostkom organizacyjnym (uzasadnienie: bez takiej przesłanki związek poszczególnych argumentów z tezą wydaje się być niejasny. Dodatkowo możemy zasadnie założyć, że autorka tekstu zna w/w warunki i budując swoją argumentację opierała się na nich).

Argumenty (7) - (9) oraz (13) wspierają szeregowo tezę (1), przy czym wydaje się, że właśnie przesłanka entymematyczna (13) stanowi ogniwo niezbędne do połączenia ich w sensowną argumentację. Dalej: dane zawarte w (10) stanowią poparcie dla (7), zaś informacje zawarte w (11) i (12) wspierają (8). W całości ten fragment analizowanej argumentacji przyjmuje następującą postać (Rys. 4.2.):

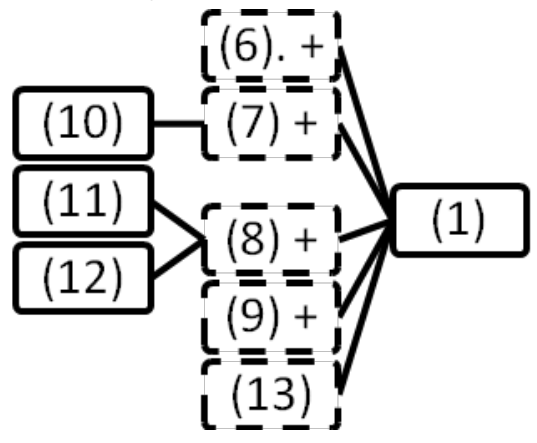




\subsection{Subargumentacja dla argumentu (2)}

Kolejnym argumentem wspierającym dowodzoną tezę w analizowanym materiale było stwierdzenie dotyczące potencjału posiadanego przez IFA. Również ten argument poparty został rozbudowaną subargumentacją, zawartą zarówno w tekście „Uzasadnienia”, jak i „Opisie jednostki”. Składają się na nią następujące elementy:

(14) IFA ma wybitne osiągnięcia naukowe (Dotychczasowa działalność Instytutu Filologï Angielskiej dokumentuje jego wybitne osiągnięcia $w$ realizacji zadań naukowych (U)).

(15) IFA ma wybitne osiągnięcia dydaktyczne (Dotychczasowa działalność Instytutu Filologii Angielskiej dokumentuje jego wybitne osiągnięcia w realizacji zadań dydaktycznych (U)).

(16) Pracownicy IFA prowadzą różnorodne badania ((...)wypływające z różnorodności prowadzonych przez pracowników badań naukowych (U)).

(17) Pracownicy IFA są otwarci na interdyscyplinarność ((..) ich [pracowników] otwartości na interdyscyplinarność (U)).

(18) IFA jest świadom wyzwań dotyczących nauki (IFA jest w pełni świadom nowych wyzwań stawianych przed nauką i dydaktyką akademicką (U)).

(19) IFA realizuje zadania wynikające z wyzwań dotyczących nauki (w ostatnich latach bardzo aktywnie i szeroko je [wyzwania] realizuje (U)).

(20) W IFA wzrasta zróżnicowanie specjalności i specjalizacji (W ostatnich dziesięciu latach na szczególne podkreślenie zasługuje rosnące wewnętrzne zróżnicowanie prowadzonych specjalności i specjalizacji ((U)).

(21) IFA stale wzbogaca i uatrakcyjnia ofertę dla kandydatów (Taka różnorodność prowadzi do stałego wzbogacania i uatrakcyjniania oferty dydaktycznej dla kandydatów (U)).

(22) IFA jest świadom wyzwań dotyczących (...) dydaktyki (IFA jest w pełni świadom nowych wyzwań stawianych przed nauką i dydaktyką akademicką (U)).

(23) IFA realizuje zadania wynikające $\mathrm{z}$ wyzwań dotyczących (...) dydaktyki (w ostatnich latach bardzo aktywnie i szeroko je [wyzwania] realizuje (U)).

(24) IFA kieruje się zasadą otwartości (kierując się zasadą otwartości (U)).

(25) IFA kieruje się zasadą dbałości o jakość ((...) dbaniem o najwyższą jakość na światowym poziomie (U)).

(26) Lista tematów badań prowadzonych w IFA (przedstawiona w OI oraz bardziej szczegółowo, z opisami zainteresowań badawczych poszczególnych pracowników w Z).

(27) Na otwarcie oczekuje nowa specjalność (IFA realizuje kilka programów dydaktycznych (...): specjalizacja filozofia i literatura anglo-amerykańska, oczekuje na uruchomienie (OI)). 
Podstawową tezę tej subargumentacji równolegle wspierają, jak się wydaje, twierdzenia (14) i (15). Pierwsze $\mathrm{z}$ nich $\mathrm{z}$ kolei wspierane jest $\mathrm{w}$ większości również równolegle przez twierdzenia (16) - (19) oraz (25) i (26). Wątpliwości mogą budzić następujące kwestie:

- Stosunek zachodzący między twierdzeniami (18) i (19) wpierającymi tezę (14) oraz twierdzeniami (22) i (23) wspierającymi tezę (15) - za wątpliwe można uznać, czy sama świadomość wyzwań dotyczacych odpowiednio nauki i dydaktyki może wskazywać na posiadanie osiagnięć naukowych bądź dydaktycznych. Przyjąć możemy, że osiągnięcia sugerują raczej pewien skończony stan, niż tylko zmiany świadomościowe, co z kolei przemawia za uznaniem obu par twierdzeń za argumentację szeregową.

- Stosunek zachodzący między twierdzeniami (24) i (25) - w tym przypadku struktura zdania, w którym są one wprowadzone (kierując się zasadq otwartości z jednoczesnym dbaniem o najwyższa jakość na światowym poziomie (U)) wydaje się sugerować argumentację szeregową. Jednak analiza twierdzeń składowych oraz ich związku z tezą wskazuje raczej na połączenie równolegle, gdyż każde $\mathrm{z}$ nich osobno i niezależnie wspiera równocześnie twierdzenia (14) i (15).

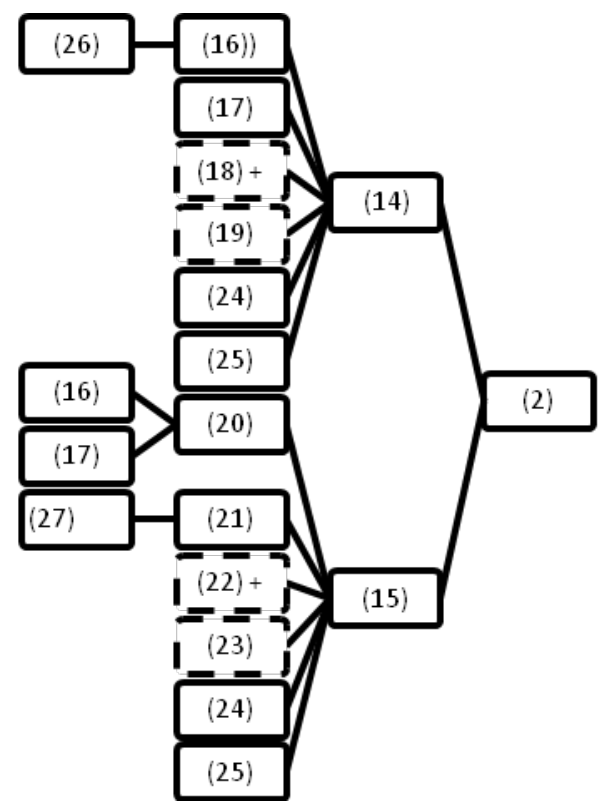

Rys.4.3.

Elementami subargumentacji dotyczącej tezy (15) są twierdzenia (20) - (23) również połączone równolegle. W analizowanym fragmencie argumentacji zastosowano również ciekawy zabieg, który możemy określić jako „ekonomizację wysiłku argumentacyjnego”, bowiem twierdzenia (16) i (17) nie tylko bezpośrednio wspierają tezę (14), ale również, pośrednio, poprzez wsparcie twierdzenia (20), tezę (15). Za taką interpretacją 
przemawia sposób wprowadzenia tych twierdzeń w analizowanym tekście: $W$ ostatnich dziesięciu latach na szczególne podkreślenie zastuguje rosnace wewnętrzne zróżnicowanie prowadzonych specjalności $i$ specjalizacji (20) wyptywajace z różnorodności prowadzonych przez pracowników badań naukowych (16) $i$ ich otwartości na interdyscyplinarność (17) (U). Ostatnimi elementami tej argumentacji są informacje zawarte w (26) wspierające twierdzenie (16) oraz twierdzenie (27) wspierające (21). W sumie więc argumentacja dotycząca subtezy (2) uzyskuje postać:

\subsection{Subargumentacja dla argumentu (4)}

Trzeci z pojawiających się w tekście argumentów wspierających główną tezę ((3) IFA już obecnie posiada wiele cech wydziału) nie posiada swojej własnej subargumentacji. Kolejne twierdzenie - (4) Potencjał IFA dynamicznie się rozwija - wspierane jest z kolei równolegle przez 3 twierdzenia:

(28) Dynamicznie rozwija się potencjał naukowy IFA (Wniosek o przeksztatcenie IFA $w$ Wydziat uzasadniony jest dynamicznym rozwojem jego potencjatu naukowego (...) w ostatnich latach (U)),

(29) Dynamicznie rozwija się potencjał dydaktyczny IFA (Wniosek o przekształcenie IFA w Wydział uzasadniony jest dynamicznym rozwojem jego potencjału (...) dydaktyczno-organizacyjnego w ostatnich latach (U)),

(30) Dynamicznie rozwija się potencjał organizacyjny IFA (Wniosek o przekształcenie IFA w Wydział uzasadniony jest dynamicznym rozwojem jego potencjału naukowego (...) w ostatnich latach (U)),

z których każda posiada stosunkowo bogatą subargumentację, której elementy stanowią następujące twierdzenia:

(31) IFA otrzymała ocenę wyróżniającą przyznaną przez Uniwersytecką Komisję Akredytacyjną ((...) przez Uniwersytecka Komisję Akredytacyjna, która $w$ kolejnych procedurach oceniających ( $w r$. 2006 i 2011) przyznała IFA ocenę wyróżniająca (U)).

(32) Kadra IFA dynamicznie się rozwija (Wykładnikami dynamicznego rozwoju sa, m.in.: rozwój kadry (U)).

(33) Wzrasta udział w projektach badawczych (Wykładnikami dynamicznego rozwoju sa, m.in.: znaczacy wzrost udziału $w$ projektach badawczych (U)).

(34) Projekty badawcze finansowane są ze środków zewnętrznych (Wykładnikami dynamicznego rozwoju sa, m.in.: znaczacy wzrost udziału $w$ projektach badawczych, $w$ szczególności tych finansowanych ze środków zewnętrznych (U)).

(35) Projekty badawcze finansowane są z międzynarodowych środków zewnętrznych (Wykładnikami dynamicznego rozwoju sa, m.in.: znaczacy wzrost udziału $w$ projektach badawczych, $w$ szczególności tych finansowanych ze środków zewnętrznych, $w$ tym międzynarodowych(U)). 
dr Victoria Kamasa: Struktura argumentacji we wniosku formalnym...

(36) Harmonijnie rozwija się współpraca IFA z ośrodkami zagranicznymi (Wykładnikami dynamicznego rozwoju sa, m.in.: harmonijny rozwój wspótpracy z ośrodkami zagranicznymi (U)).

(37) IFA posiada wiodącą pozycję wśród krajowych i światowych ośrodków prowadzących badania w dziedzinach obecnych w IFA (Wykładnikami dynamicznego rozwoju sa, m.in.: wiodąca pozycja IFA wśród krajowych $i$ światowych ośrodków prowadzących badania $w$ dziedzinach obecnych $w$ IFA (U)).

(38) IFA posiada wiodącą pozycję wśród krajowych ośrodków prowadzących badania w dziedzinach obecnych w IFA (Wykładnikami dynamicznego rozwoju sa, m.in.: wiodaca pozycja IFA wśród krajowych (...) ośrodków prowadzacych badania $w$ dziedzinach obecnych w IFA (U)).

(39) IFA posiada wiodącą pozycję wśród światowych ośrodków prowadzących badania w dziedzinach obecnych w IFA (Wykładnikami dynamicznego rozwoju sa, m.in.: wiodąca pozycja IFA wśród (...) światowych ośrodków prowadzacych badania $w$ dziedzinach obecnych w IFA (U)).

(40) Rozwój współpracy z innymi jednostkami UAM (Wykładnikami dynamicznego rozwoju sa, m.in.: znaczący rozwój wspótpracy $z$ innymi jednostkami UAM (również $w$ ramach $W N$ ) (U)).

(41) Rozwój współpracy $\mathrm{z}$ innymi uczelniami (Wykładnikami dynamicznego rozwoju są, m.in.: znaczący rozwój współpracy z (...) innymi uczelniami (U)).

(42) Wzrost interdyscyplinarności badań (Wykładnikami dynamicznego rozwoju sa, m.in.: rosnąca interdyscyplinarność badań (U)).

(43) Oferta dydaktyczna IFA jest systematycznie rozszerzana (Wykładnikami dynamicznego rozwoju sa, m.in.: systematyczne rozszerzanie oferty dydaktycznej (U)).

(44) IFA realizuje projekty dydaktyczne z innymi jednostkami WN oraz UAM (IFA realizuje kilka programów dydaktycznych wspólnie $Z$ innymi jednostkami Wydziału Neofilologii $i$ innych wydziałów UAM: [wymienione konkretne kierunki] (OI)).

(45) Dane liczbowe dotyczące liczby pracowników administracyjnych, inżynieryjno-technicznych i naukowo technicznych (OI).

(46) IFA dysponuje sprawnym personelem sekretariatu, pracowni komputerowej i pracowni wydawniczej (IFA dysponuje sprawnym $i$ nowoczesnym personelem sekretariatu oraz pracowni komputerowej i wydawniczej. (OI)).

(47) Dane liczbowe dotyczące zmian liczby osób z poszczególnymi tytułami naukowymi (liczba samodzielnych pracowników nauki $w$ 2003 roku 22, w 2011 - 28; liczba adiunktów w 2003 roku 33, w 2011 roku $56(\mathrm{U}))$.

(48) IFA pozyskała w 2010 r. 14 grantów z MNiSW ( $W$ roku 2010 pracownicy IFA uzyskali aż 14 grantów MNiSW w konkursie 39 i 40 (OI)). 
(49) IFA pozyskała znaczące środki programu EFS POKL 4.1.1. ( $W$ roku 2010 IFA pozyskał znaczace środki z programu EFS POKL 4.1.1. (OI)).

(50) IFA aktywnie uczestniczy w programie ERASMUS (IFA od wielu lat aktywnie uczestniczy $w$ programie wymiany kadry $i$ studentów LLP ERASMUS (OI)).

(51) Lista jednostek, z którymi IFA współpracuje w ramach programu ERASMUS (Z).

(52) Lista ośrodków akademickich, z którymi współpracuje IFA (Ponadto IFA wspótpracuje z licznymi uniwersytetami i instytucjami naukowymi $w$ Europie i na świecie: [wymienione konkretne ośrodki badawcze](OI)).

(53) W IFA funkcjonuje Interdyscyplinarne Centrum Przetwarzania Mowy i Języka (Od roku $2005 \mathrm{w}$ IFA funkcjonuje Interdyscyplinarne Centrum Przetwarzania Mowy i Języka (Center for Speech and Language Processing), którego dyrektorem jest prof. $d r$ hab. Katarzyna Dziubalska-Kotaczyk, Dyrektor IFA UAM. Centrum to międzywydziałowa jednostka badawcza (...) (OI)).

(54) Lista międzynarodowych projektów, w których udział biorą pracownicy IFA $(Z)$.

Twierdzenia wspierające główną tezę stanowią argumentację równoległą. Najbardziej rozbudowana jest subargumentacja twierdzenia (28), składają się na nią bowiem twierdzenia od (31) do (41), a także dane zawarte w (47), które wspierają twierdzenie (32), twierdzenia (48) i (49) wspierające równolegle twierdzenie (34), twierdzenia (50) - (52) wspierając również równolegle twierdzenie (36) oraz dane zawarte w (54) wspierające z kolei twierdzenie (51). Z kolei twierdzenie (29) wspierane jest bezpośrednio twierdzeniami (42) - (44). Tutaj również argumentacja ma charakter równoległy, podobnie jak w przypadku twierdzeń (45) i (46) stanowiących subargumentację dla twierdzenia (30).

Wątpliwości budzić może zależność zachodząca między twierdzeniami (33), (34) i (35). Sposób ich prezentacji w tekście: znaczacy wzrost udziatu $w$ projektach badawczych, $w$ szczególności tych finansowanych ze środków zewnętrznych, w tym międzynarodowych (U) sugerować może istnienie związku pomiędzy poszczególnymi jego komponentami ujętymi w wyżej wymienionych twierdzeniach, a więc argumentację szeregową. Przyjęte przez nas kryterium różnicowania typów argumentacji, a więc absolutna niezbędność wszystkich przesłanek do wsparcia twierdzenia $\mathrm{w}$ jakimkolwiek stopniu, wydaje się nie mieć tutaj zastosowania, co z kolei przemawia za uznaniem tej argumentacji za równoległą.

Cała subargumentacja przybiera więc strukturę zaprezentowaną na rys. 4.4 . 
dr Victoria Kamasa: Struktura argumentacji we wniosku formalnym...

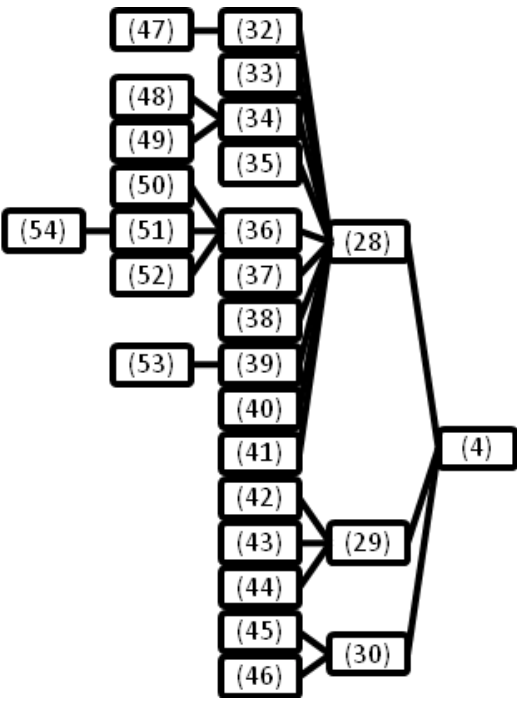

Rys. 4.4 .

\subsection{Subargumentacja dla argumentu (5)}

Ostatnia z subargumentacji wyróżnionych w analizowanym tekście dotyczy nie wyrażonego explicite twierdzenia (5) Otwarcie WA będzie korzystne dla UAM. Argumentacja ta, choć podobnie jak pozostałe, w zasadniczej swej części ujęta jest w jednym akapicie „Uzasadnienia”, ma zdecydowanie najbardziej złożony charakter. Wyróżnić w niej możemy zarówno najwięcej tez bezpośrednio wspierających twierdzenie (5) jak i największą liczbę kolejnych poziomów subargumentacji. Składają się na nią następujące twierdzenia:

(55) Zadania WA wpisują się $\mathrm{w}$ misję i strategię UAM (Zadania proponowanego nowego Wydziatu wpisuja się znakomicie $w$ misję $i$ strategię rozwoju Uniwersytetu im. Adama Mickiewicza w Poznaniu. (U)).

Twierdzenie to uzasadniane jest bezpośrednio przez (56) i pośrednio przez (57), które wspiera (56):

(56) W IFA opracowano Strategię Rozwoju IFA, w oparciu o cele strategiczne UAM (Strategię Rozwoju IFA, $w$ oparciu o cele strategiczne UAM. (U)).

(57) W IFA powołano zespół, który opracował Strategię Rozwoju IFA ( $W$ konsekwencji powstania Strategii Rozwoju UAM na Lata 20o9-19 w IFA powotano specjalny zespót, który opracowat Strategię Rozwoju IFA (U)).

Kolejny element równoległej argumentacji tezy (5) stanowią twierdzenia (58) i (59), z których każde wydaje się wsparte twierdzeniem (60):

(58) WA będzie stanowił nową jakość obecną tylko na UAM ([WA] stanowiłby zatem nowa jakość obecna jedynie na $U A M(\mathrm{U}))$.

(59) UAM będzie uznawany za uczelnię uznającą wyjątkową rolę języka angielskiego (Nasz Uniwersytet jawiłby się jako uczelnia uznająca 
wyjątkowa rolę języka angielskiego jako lingua franca $w$ świecie (U)).

(60) WA będzie jedynym takim wydziałem w Polsce (Wydział Anglistyki bytby pierwszym tego rodzaju wydziałem $w$ Polsce (U)).

Następnym elementem analizowanego fragmentu tekstu jest stosunkowo rozbudowana wypowiedź dotycząca konieczności tworzenia na UAM programów studiów po angielsku. Wydaje się, że pojawiające się w tekście twierdzenia (63) - (72) połączone są z główną tezą przy pomocy trzech przesłanek: ukrytych przesłanek (61) i (62) oraz twierdzenia (63) stanowiących wspólnie argumentację równoległą, za czym przemawia fakt, że żadna $\mathrm{z}$ nich $\mathrm{w}$ izolacji nie wspiera twierdzenia, że UAM skorzysta na stworzeniu WA:

(61) (przesłanka ukryta) UAM potrzebuje programów studiów w języku angielskim. Uzasadnienie: twierdzenie takie, choć nie wyrażone explicite $\mathrm{w}$ tekście wydaje się zgodne $\mathrm{z}$ prezentowanymi $\mathrm{w}$ nim przekonaniami, za czym przemawiają np. sformułowania: przyciagnąć jak najwięcej studentów z zagranicy (U), przygotowaniu programów anglojęzycznych (U).

(62) (przesłanka ukryta) WA jest w stanie zapewnić wykształcenie nowych anglistów. Uzasadnienie: Na obecność tego elementu w analizowanej argumentacji wskazuje stwierdzenie: Oczywista role $w$ przygotowaniu programów anglojęzycznych spetnia angliści, a skala tego przedsięwzięcia będzie wymagata rozwinięcia struktur jednostki (U). Wnioskować z niego możemy, że to właśnie dzięki rozbudowanym strukturom WA możliwe będzie zapewnienie anglistów, którzy podejmą się zadania tworzenia programów studiów po angielsku.

(63) Angliści będą pełnić istotną rolę w przygotowaniu programów anglojęzycznych (Oczywista role $w$ przygotowaniu programów anglojęzycznych spetnią angliści (U)).

Z kolei szeregową subargumentację dla (61) stanowią:

(64) Konieczna jest zmiana oferty dydaktycznej UAM (konieczna będzie zmiana oferty dydaktycznej UAM(U)).

(65) Konieczne jest przyciągnięcie jak największej liczby studentów z zagranicy (konieczna będzie zmiana oferty dydaktycznej UAM tak, aby przyciągnąć jak najwięcej studentów z zagranicy (U)).

Twierdzenie (64) wsparte jest zaś bezpośrednio przez (66) i pośrednio przez (67):

(66) Nastapi długotrwały spadek liczby studentów (długotrwały spadek liczby studentów w ciągu nadchodzących kilkunastu lat (U)).

(67) Prognoza demograficzna wskazuje na długotrwały spadek liczby studentów (Wobec prognozowanej tendencji demograficznej, która przyniesie dtugotrwaty spadek liczby studentów $\mathrm{w}$ ciągu nadchodzących kilkunastu lat $(U))$.

Kolejnym elementem analizowanego wniosku jest równoległa argumentacja dla twierdzenia (62), na którą składają się: 
dr Victoria Kamasa: Struktura argumentacji we wniosku formalnym...

(68) Skala przedsięwzięcia przygotowania programów anglojęzycznych wymaga rozwinięcia struktur IFA do WA (skala tego przedsięwzięcia będzie wymagała rozwinięcia struktur jednostki (U)).

(69) Istnieje możliwość połączenia doświadczeń IFA i KJO (powstanie możliwość potaczenia najlepszych doświadczeń Instytutu i Kolegium $w$ tym zakresie (U)),

wspierana przez:

(70) Do IFA przeszła część kadry Kolegium Języków Obcych (Już w tej chwili dzięki przejściu części kadry Kolegium Języków Obcych UAM do IFA (U)) oraz:

(71)Istnieje możliwość zapewnienia wysokiej jakości zajęć komponentu dydaktyczno-pedagogicznego (powstanie możliwość (...) zapewnienia wysokiego poziomu zajęć komponentu dydaktyczno-pedagogicznego (U)),

Wspierana przez (70) oraz:

(72) W IFA utworzono specjalistyczną Pracownię Kształcenia Nauczycieli (Już $w$ tej chwili dzięki (...) utworzeniu specjalistycznej Pracowni Ksztatcenia Nauczycieli (U)).

Analizowana tutaj teza (5) wspierana jest równolegle przez twierdzenia:

(73) Dostosowanie wielkości WN do wielkości innych wydziałów na UAM (Kolejnq korzyścia dla UAM jest dostosowanie rozmiaru wydziałów do standardu na naszej uczelni poprzez wydzielenie Anglistyki z WN (U)).

(74) UAM zyska więcej jednostek z pierwszą kategorią (UAM natomiast zyskatby więcej jednostek z pierwszq kategoriq (U)),

wraz z jego subargumentem:

(75) Oba wydziały neofilologiczne uzyskają pierwszą kategorię (przy bardzo prawdopodobnym zatożeniu, że oba wydziaty neofilologiczne tę [pierwszą] kategorię uzyskaja (U)).

oraz wsparta szeroką argumentacją przez przesłankę ukrytą:

(76) (przesłanka ukryta) WN skorzysta na powstaniu WA Uzasadnienie: Liczne cytowane poniżej stwierdzenia wskazują, że autorka tekstu widzi liczne korzyści dla WN wynikające z oddzielenia się WA, zaś dodanie tej przesłanki porządkuje schemat argumentacji i czyni go, jak się wydaje, bardziej przejrzystym.

Wspomniane już wsparcie (76) stanowią:

(77) Dwa wydziały neofilologiczne będą skuteczniej lobbować we wspólnych sprawach neofilologii w kraju (Dwa wydziały neofilologiczne przyczynia się do skuteczniejszego lobbingu we wspólnych sprawach neofilologii w kraju (U)).

(78) Zmiana wielkości WN ułatwi funkcjonowanie WN (Zmiana ta [odejście IFA] ułatwi funkcjonowanie (...) również Wydziałowi Neofilologii (U)).

(79) Zmiana wielkości WN ułatwi administrowanie WN (Zmiana ta [odejście IFA] ułatwi (...) administrowanie również Wydziałowi Neofilologii (U)). 
(80) Zmiana wielkości WN wyrówna szanse jednostek mniejszych od IFA (Zmiana ta [odejście IFA] (...) wyrówna szanse jednostek mniejszych od IFA (U))

wraz z subargumentem:

(81) IFA jest największym instytutem na WN (odejście największego Instytutu (U)).

(82) Odejście IFA stworzy szansę i przestrzeń do zagospodarowania i działania (odejście największego Instytutu stworzy szansę $i$ przestrzeń do zagospodarowania i działania (U)).

(83) Odejście IFA stworzy szansę i przestrzeń dla osobnej polityki kadrowej (odejście największego Instytutu stworzy szansę i przestrzeń do (...) oddzielnej polityki kadrowej (U)).

(84) Odejście IFA stworzy szansę i przestrzeń dla nowych wyzwań (odejście największego Instytutu stworzy szansę i przestrzeń (...) nowych wyzwań (U)).

(85) Odejście IFA stworzy szansę i przestrzeń dla większej równowagi (odejście największego Instytutu stworzy szansę i przestrzeń do (...) większej równowagi (U)) wraz z subargumentem (81).

(86) IFA będzie kontynuować współpracę z WN (IFA deklaruje gotowość do kontynuowania (...) wspótpracy z Wydziałem Neofilologii (U)).

(87) IFA będzie rozwijać współpracę z WN (IFA deklaruje gotowość do (...) dalszego rozwijania współpracy z Wydziałem Neofilologii (U)).

Ostatnim z argumentów równolegle wspierającym podstawową tezę (5) jest:

(88) Stworzenie WA doprowadzi do braku dublowania zadań na jednym wydziale (bez dublowania tych zadań na jednym wydziale (U)).

W bezpośrednim sąsiedztwie twierdzenia (88) występują w tekście:

(89) IFA prowadzi swoje własne Studium Doktoranckie (Nowy wydziat bytby kolejnym prowadzacym (od 8 lat) wtasne Studium Doktoranckie (U))3,

(90) WA będzie prowadził swoje własne Studium Doktoranckie (Nowy wydziat bytby kolejnym prowadzacym (od 8 lat) własne Studium Doktoranckie (U)),

(91) IFA posiada uprawnienia do nadawania doktoratów i habilitacji (Nowy wydziat bytby kolejnym (...) posiadajacym uprawnienia do nadawania doktoratów i habilitacji (U)),

(92) WA będzie posiadał uprawnienia do nadawania doktoratów i habilitacji (Nowy wydziat bytby kolejnym (...) posiadajacym uprawnienia do nadawania doktoratów i habilitacji (U)),

jednak bezpośredni związek z twierdzeniem (88), którego wydają się dotyczyć, pozostaje niejasny. Dlatego też proponujemy dołączenie do argumentacji dwóch przesłanek ukrytych:

3 Ze względu na pewną niespójność dotyczącą chronologii: Nowy wydział byłby kolejnym prowadzącym (od 8 lat) własne Studium Doktoranckie oraz posiadającym uprawnienia do nadawania doktoratów i habilitacji (U) zasadne wydaje się podzielenie tak sformułowanego stwierdzenia na każdorazowo dwa twierdzenia: jedno dotyczące przyszłości, drugie zaś teraźniejszości. 
dr Victoria Kamasa: Struktura argumentacji we wniosku formalnym...

(93) Obecnie IFA dubluje zadania wydziału, której subargumentację stanowić będą twierdzenia (89) i (91).

(94) WA nie będzie dublował zadań, wspartą z kolei przez twierdzenia (90) i (91).

W ostateczności uzyskujemy zatem następującą strukturę przedstawiona na rys.4.5:

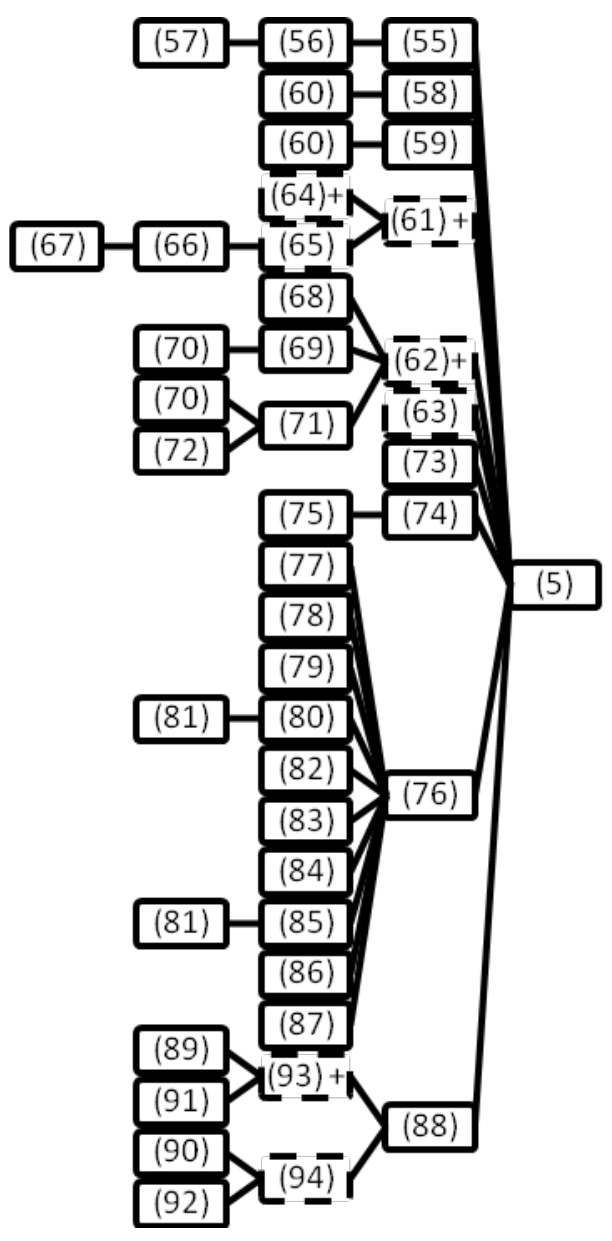

Rys. 4.5

\section{Ocena argumentacji}

Zgodnie z zaproponowanym na początku porządkiem, ocenę argumentacji rozpoczniemy od oceny poszczególnych subargumentacji. Aby uczynić ocenę tę bardziej czytelną, dla każdej subargumentacji przedstawimy jeszcze raz jej diagram wraz ze skróconym opisem znajdujących się w nim twierdzeń. 


\subsection{Ocena stopnia akceptowalności dla twierdzenia (1)}

Dla tej argumentacji zaproponowaliśmy następującą strukturę:

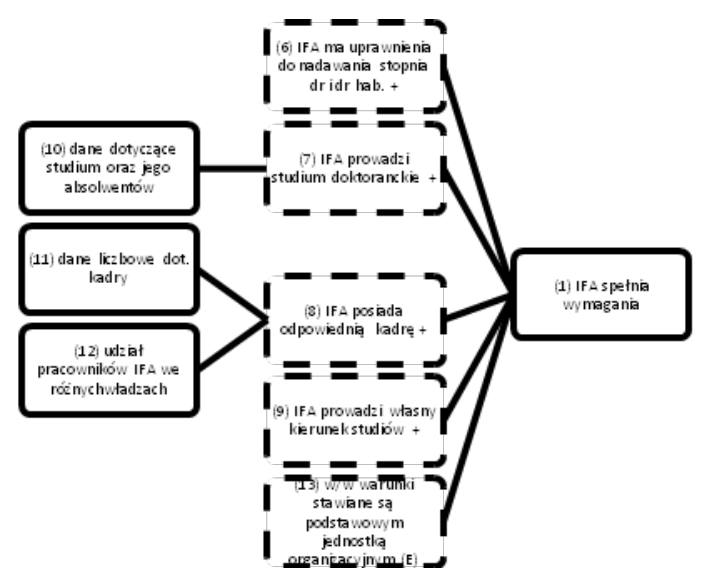

Rys. 5.1.

Przesłanki (6), (9), (10) (11) i (12) przyjęte bez uzasadnienia oceniamy jako pewne, ponieważ przyjmujemy, że autorka argumentacji podaje w niej prawdziwe dane oraz ponieważ istnieje możliwość potwierdzenia tych danych. Również przesłankę (13) oceniamy jako pewną $(\mathrm{A}(13)=5)$ ze względu na informacje zawarte w Ustawie o Szkolnictwie Wyższym.

Inferencje:

$\mathrm{S}(10 / 7)=5$, ponieważ posiadanie studentów i absolwentów SD jednoznacznie świadczy o posiadaniu SD;

$\mathrm{S}(11 / 8)=5$, ponieważ liczba kadry podana $\mathrm{w}$ dokumencie jednoznacznie świadczy o posiadaniu przez IFA wymaganej liczby kadry.

$\mathrm{S}(12 / 8)=3$, ponieważ związek między udziałem we władzach oraz odpowiedniością kadry ze względu na wymagania ustawowe nie jest jasny;

$\mathrm{S}(6+7+8+9+13 / 1)=5$, ponieważ wynikanie ma charakter dedukcyjny.

Po zastosowaniu zasad obliczania stopnia akceptowalności tezy otrzymujemy: $\mathrm{A}(7)=5, \mathrm{~A}(8)=5$ i dla uzasadniajej $\mathrm{w}$ tej argumentacji subtezy (1) $-\mathbf{A ( 1 )}=\mathbf{5}$. 
dr Victoria Kamasa: Struktura argumentacji we wniosku formalnym...

\subsection{Ocena stopnia akceptowalności dla twierdzenia (2)}

Dla drugiego z elementów analizowanej argumentacji zaproponowaliśmy poniższą strukturę:

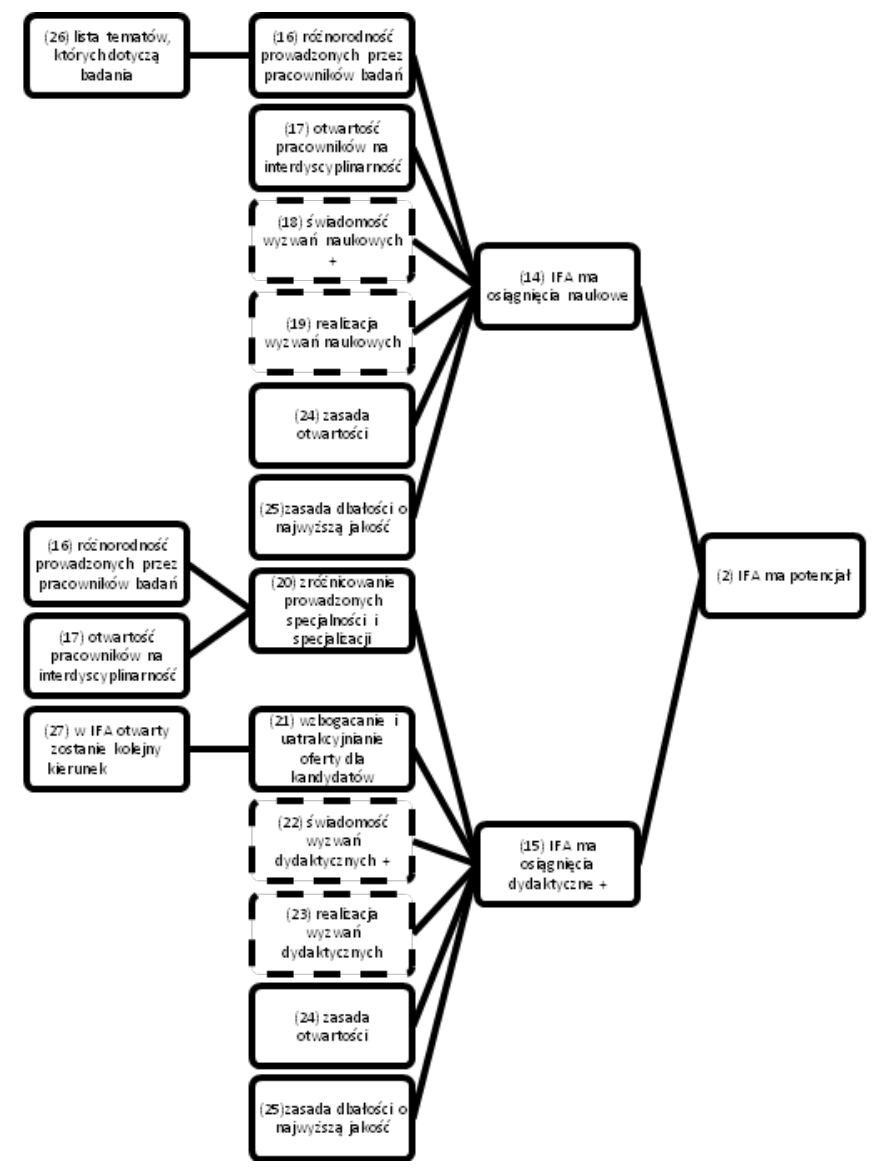

Rys. 5.2.

Wśród przedstawionych bez dalszego uzasadnienia przesłanek, jako pewne oceniliśmy przesłanki (16), (26) oraz (27), gdyż podobnie jak w przypadku poprzedniej subargumentacji, dotyczą one danych podlegających sprawdzeniu. Pozostałym przesłankom przypisano stopień akceptowalności 4, gdyż z jednej strony mają one charakter opinii, z drugiej jednak strony autorce tekstu jako Dyrektor IFA przypisać możemy duży stopień kompetencji do wydawania takich opinii, co z kolei silnie je uprawdopodobnia.

W odniesieniu do siły inferencji możemy przyjąć, że $S(26 / 16)=5$, gdyż przytoczona lista jednoznacznie wskazuje na różnorodność prowadzonych badań, $\mathrm{S}(16 / 20)=3$ oraz $\mathrm{S}(17 / 20)=3$, gdyż nie zachodzi konieczny ani jak się wydaje nawet zasadniczo prawdopodobny związek między liczbą prowadzonych badań oraz otwartością na interdyscyplinarność a różnorodnością prowadzonych działań dydaktycznych (na tej podstawie 
otrzymujemy $\mathrm{A}(20)=3$ ), $\mathrm{S}(27 / 21)=5$ (z czego po obliczeniach otrzymujemy $\mathrm{A}(21)=5)$, gdyż otwarcie kolejnego kierunku stanowi niewątpliwie wzbogacenie oferty dydaktycznej. Ocena pozostałych inferencji występujących w tej subargumentacjił nastręcza problemów, gdyż związki te są silnie oparte na implicite przyjmowanych normach, dotyczących tego, co wyznacza osiągnięcia naukowe bądź dydaktyczne. Jeśli przyjmiemy, że wymieniane $\mathrm{w}$ analizowanym tekście działania i postawy są elementem takich osiągnięć, otrzymamy silę inferencji 4 (a w rezultacie A(14) $=4$ oraz $\mathrm{A}(15)=4)$, w przeciwnym wypadku twierdzenia uzyskają status nieistotnych ze względu na tezę, którą mają uzasadniać, tym samym siła inferencji będzie wynosiła 3 (a w rezultacie $\mathrm{A}(14)=3$ oraz $\mathrm{A}(15)=3$ ).

Związek między posiadaniem osiągnięć naukowych i dydaktycznych a posiadaniem potencjału (czyli S(14/2) i S(15/2)) wydaje się dość silny, gdyż trudno jak się wydaje wyobrazić sobie jednostkę akademicką posiadającą zarówno osiągnięcia dydaktyczne jak i naukowe, która nie posiada potencjału, zatem $S(14 / 2)=4$ i $S(15 / 2)=4$. Cała subargumentacja przyjmie stopień akceptowalności $\mathrm{w}$ zależności od rozstrzygnięcia opisanego powyżej problemu dotyczącego norm $\mathbf{A ( 2 ) = 3}$ lub $\mathbf{A ( 2 ) = 4}$.

\subsection{Ocena stopnia akceptowalności dla twierdzenia (4)}

Zgodnie z zaproponowaną wyżej analizą w przypadku tej subargumentacji mamy do czynienia z następującą strukturą: 
dr Victoria Kamasa: Struktura argumentacji we wniosku formalnym...

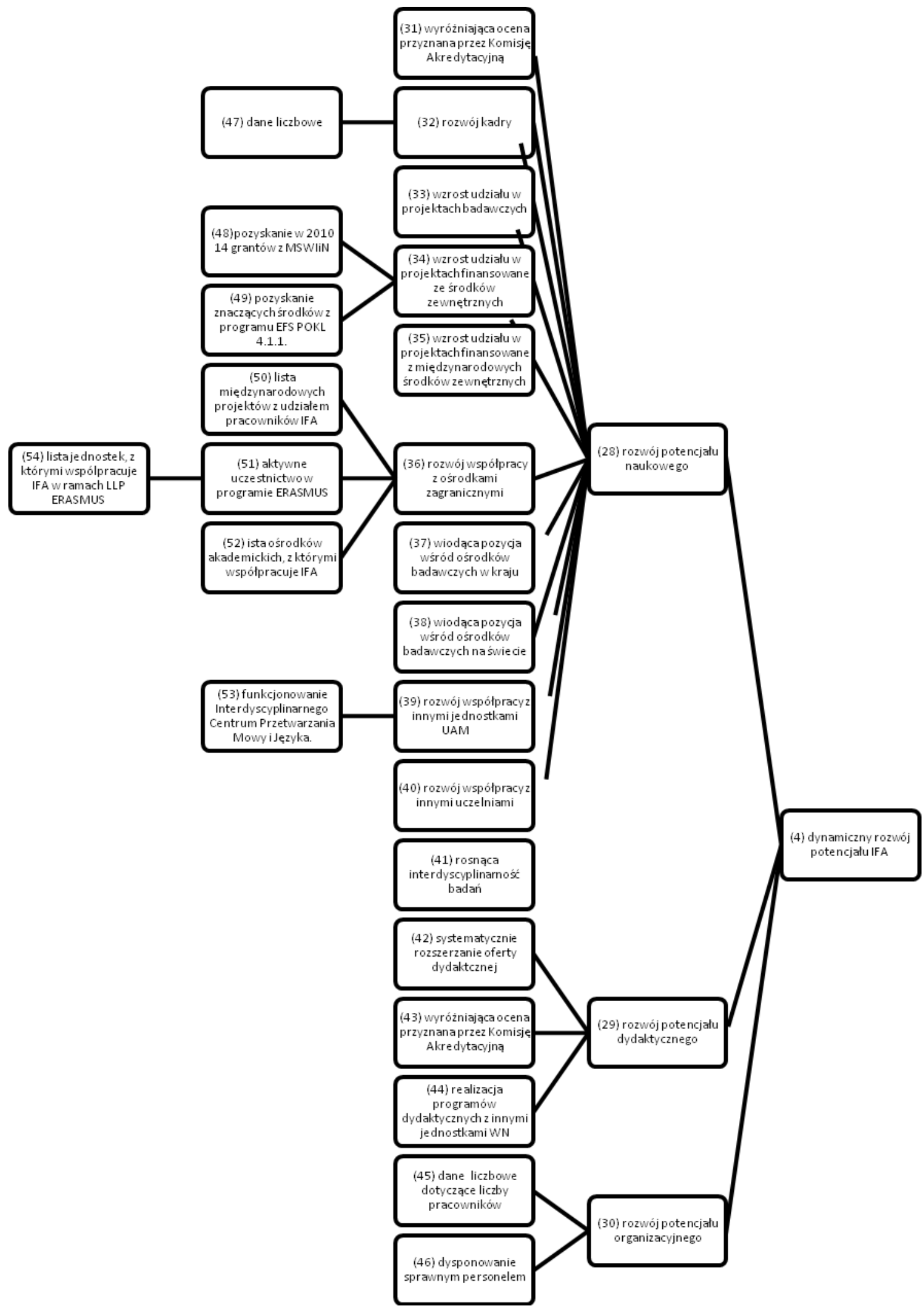

Rys. 5.3. 
Podobnie jak w poprzednich przypadkach, za pewne uznamy te przesłanki, które opierają się na danych podlegających sprawdzeniu, a więc (31), (42), (43), (44), (45), (47), (48), (49), (50), (52), (53), (54), zaś pozostałym dalej nie uzasadnianym przesłankom przypiszemy stopień akceptowalności 4, ze względu na ich oparcie na opinii autorki tekstu oraz jej kompetencję jako osoby oceniającej. Siłę inferencji $\mathrm{S}(47 / 32)$ oraz S(54/51) ocenimy jako 5, ponieważ zaprezentowane dane jednoznacznie potwierdzają wspierane nimi tezy, otrzymując $\mathrm{w}$ efekcie $\mathrm{A}(32)=5$ oraz $\mathrm{A}(51)=5$. Przejścia inferencyjne $\mathrm{S}(32 / 28), \mathrm{S}(33 / 28), \mathrm{S}(34 / 28), \mathrm{S}(35 / 28)$, $\mathrm{S}(36 / 28), \quad \mathrm{S}(37 / 28), \quad \mathrm{S}(38 / 28), \quad \mathrm{S}(39 / 28), \quad \mathrm{S}(40 / 28), \quad \mathrm{S}(41 / 28)$ oraz $\mathrm{S}(42 / 29)$ nie dowodzą jednoznacznie tez, których dotyczą, jednak uprawdopodobniają je $\mathrm{w}$ znacznym stopniu, dlatego też przypiszemy im wartość 4.

Wątpliwości budzi natomiast ocena siły następujących przejść inferencyjnych: $\mathrm{S}(31 / 28), \mathrm{S}(48 / 34), \mathrm{S}(49 / 34), \mathrm{S}(50 / 36), \mathrm{S}(51 / 36)$, $\mathrm{S}(52 / 36), \mathrm{S}(53 / 39), \mathrm{S}(43 / 29), \mathrm{S}(44 / 29), \mathrm{S}(45 / 30)$ oraz $\mathrm{S}(46 / 30)$, gdyż zawarte w przesłankach dane bądź opinie dotyczą stanu obecnego, zaś wspierane przez nie tezy zachodzenia rozwoju, a więc zmiany. Wydaje się, by móc stwierdzić zajście zmiany, konieczne jest porównanie przynajmniej dwóch stanów (przed zmianą i po zmianie), dlatego też przesłanki te uznamy za nieistotne ze względu na tezy, których dotyczą, przypisując im siłę inferencji 3 .

Po dokonaniu odpowiednich obliczeń otrzymujemy $\mathrm{A}(28)=4, \mathrm{~A}(29)=4$ oraz $\mathrm{A}(30)=3$. Siłę inferencji zachodzącą między tymi twierdzeniami a dowodzoną subtezą ocenimy jako 4, ponieważ rozwój każdego ze wskazanych potencjałów w sposób istotny uprawdopodobnia rozwój potencjału IFA jako całości, otrzymując w efekcie $\mathbf{A}(\mathbf{4})=\mathbf{4}$.

\subsection{Ocena stopnia akceptowalności dla twierdzenia (5)}

Ze względu na znaczące rozbudowanie subargumentacji dla twierdzenia (5), ocenimy najpierw bardziej rozbudowane argumentacje subtez $(61)+(62)+(63),(76)$ oraz (88) wspierających tezę (5), którą to ocenę następnie podsumujemy, otrzymując stopień akceptowalności badanej tezy.

Dla wspomnianej wyżej argumentacji szeregowej przyjęliśmy następującą strukturę: 


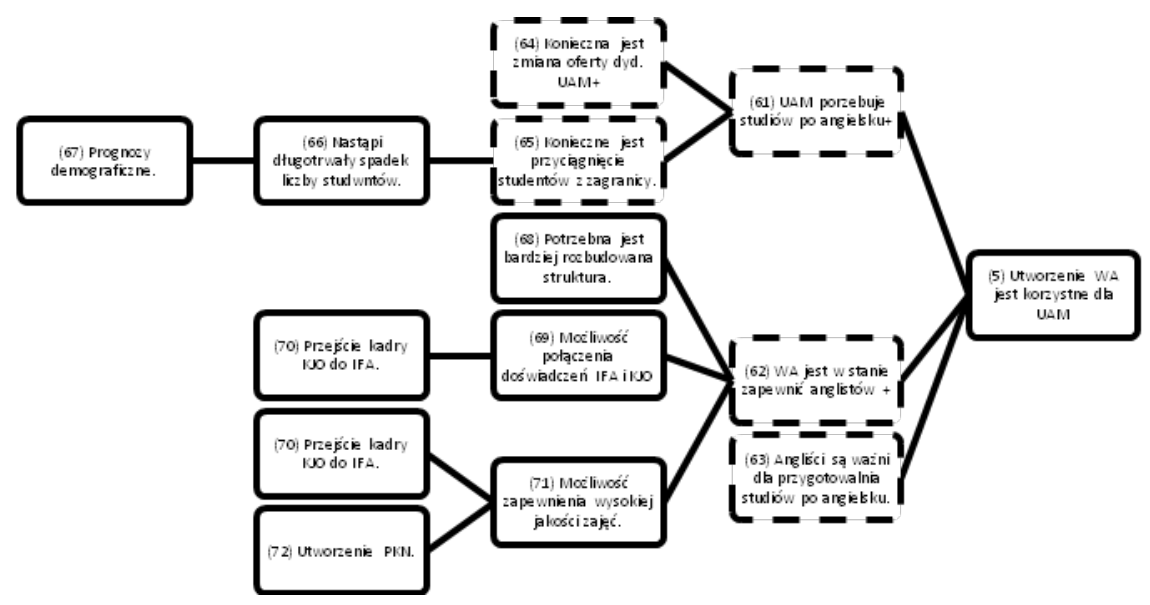

Rys. 5.4.1

Wśród pojawiających się $\mathrm{w}$ powyższej argumentacji przesłanek przyjmowanych bez dalszego uzasadnienia za pewne uznamy (67), (70) oraz (72), gdyż odnoszą się one do faktów podlegających weryfikacji. Z kolei jako bardzo prawdopodobne, choć nie pewne, bo oparte na opinii twórcy argumentacji, ocenimy przesłanki (64) i (68). Zasadnicze wątpliwości budzi natomiast stopień akceptowalności przesłanki (63) - nie jest bowiem jasne, ani wyjaśnione w którejkolwiek części analizowanego tekstu, na czym będzie polegać oczywista rola anglistów $w$ przygotowaniu programów anglojęzycznych (U). Wydaje się, że programy anglojęzyczne dla poszczególnych kierunków z powodzeniem mogą przygotowywać specjaliści w danych dziedzinach władający językiem angielskim. Przykład ten wskazuje, że ocena prawdziwości twierdzenia (63) jest przynajmniej wątpliwa, dlatego też $\mathrm{A}(63)=3$.

Za silne przejścia inferencyjne, w których prawdziwość przesłanki jednoznacznie wskazuje na prawdziwość tezy uznamy S(67/66) (prognozy demograficzne jednoznacznie wskazują tendencje dotyczące liczby kandydatów) oraz $\mathrm{S}(70 / 69)$ (połączenie kadry $\mathrm{z}$ dwóch ośrodków jednoznacznie zapewnia możliwość połączenia jej doświadczeń) oraz $(61+62+63 / 5)$ (wskazane elementy jednoznacznie wskazują na to, że otwarcie WA realizuje jedną z potrzeb UAM, czyli jest dla niego korzystne). Z kolei siłę inferencji 4 przypiszemy następującym przejściom:

- $\mathrm{S}(64+65)$, ponieważ z jednej strony możliwe do pomyślenia jest przyciągnięcie kandydatów z zagranicy także przy pomocy studiów w innych językach, z drugiej jednak - studia po angielsku wydają się najbardziej uniwersalnym rozwiązaniem;

- $\mathrm{S}(70 / 71)$ i $\mathrm{S}(72 / 71)$, ponieważ żaden $\mathrm{z}$ wymienionych faktów nie wskazuje jednoznacznie na wysoką jakość dydaktyki, jednak w sposób istotny ją uprawdopodabnia;

- S(68/62), ponieważ zależność ta ma charakter opinii, a osoba wypowiadająca się na jej temat może zostać uznana za posiadającą kompetencję do wygłaszania takiej opinii; 
- $\mathrm{S}(69 / 62)$ oraz $\mathrm{S}(71 / 62)$, ponieważ żadna $\mathrm{z}$ tych przesłanek nie prowadzi w sposób konieczny do możliwości zapewnienia anglistów przez WA, jednak czyni to bardzo prawdopodobnym.

Natomiast za irrelewantną przesłankę uznamy (66) dla tezy (65) (uzyskując tym samym $\mathrm{S}(66 / 65)=3$ ), ponieważ nie jest jasne, dlaczego spadek liczby kandydatów na studia miałby prowadzić do konieczności przyciągania studentów z zagranicy.

Po dokonaniu obliczeń otrzymujemy kolejno: $A(66)=5, A(65)=3$, $\mathrm{A}(61)=3, \quad \mathrm{~A}(69)=5, \quad \mathrm{~A}(71)=4, \mathrm{~A}(62)=4$. Zgodnie $\mathrm{z}$ założeniem $\mathrm{o}$ sile argumentacji szeregowej odpowiadającej jej najsłabszemu ogniwu (Tokarz, 2006, str. 142), ta subargumentacja prowadzi do akceptowalności tezy (5) $\mathrm{w}$ stopniu 3.

Kolejną rozbudowaną argumentację dla subtezy (5) stanowi argumentacja dotycząca twierdzenia (76), której analiza doprowadziła do identyfikacji następującej struktury:

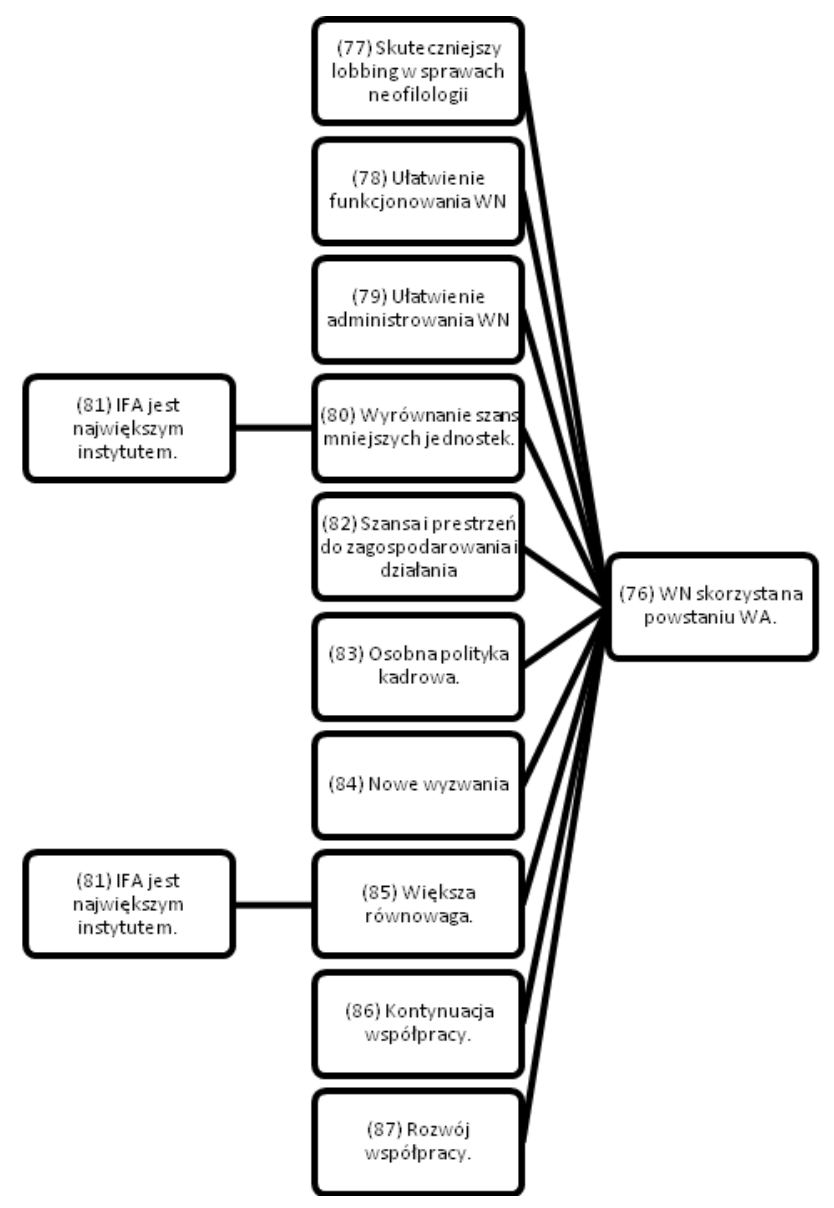

Rys. 5.4.2

Ten fragment argumentacji jest rozbudowaną argumentacją równoległą, $\mathrm{z}$ dużą liczbą przesłanek nie podlegających dalszemu dowodzeniu. Wśród nich za pewne uznamy (81), gdyż stanowi ona fakt 
podlegający weryfikacji, (83), jako że rozdzielenie IFA oraz WN w sposób oczywisty prowadzi do osobnej polityki kadrowej, (77), ponieważ powstanie kolejnego wydziału neofilologicznego prowadzi $\mathrm{np}$. do zwiększenia liczby głosów neofilologów w rozmaitych gremiach oraz (86) i (87), ponieważ stanowią one deklarację osoby mającej zasadniczy wplyw na realizację tej deklaracji. Wysoki stopień prawdopodobieństwa przyznamy przesłankom (78) oraz (79), ponieważ zawierają one opinię, jednak ze względu na kompetencję i doświadczenie autorki opinii, może ona zostać uznana za bardzo prawdopodobną. Wydaje się natomiast, że trudny do oceny jest poziom prawdziwości sądów (82) oraz (84), nie jest bowiem jasne, dlaczego odejście IFA będzie tworzyć szansę i przestrzeń do zagospodarowania i działania oraz nowe wyzwania.

Jeśli chodzi o siły przejść inferencyjnych, to zostały one ocenione następująco:

- $\mathrm{S}(77 / 76)=4$, ponieważ wzrost skuteczności lobbingu w sprawach neofilologii z dużym prawdopodobieństwem przyniesie korzyść $\mathrm{WN}$;

- $\mathrm{S}(78 / 76)=5$ oraz $\mathrm{S}(79 / 76)=5$, ponieważ łatwiejsze funkcjonowanie i administrowanie mogą zostać uznane za jednoznaczne korzyści dla $\mathrm{WN}$;

- $\mathrm{S}(81 / 80)=4$, ponieważ odejście największej jednostki nie prowadzi jak się wydaje w sposób konieczny do wyrównania szans pozostałych, jednak w sposób istotny to uprawdopodabnia;

- $\mathrm{S}(80 / 76)=4$, ponieważ równość szans wszystkich jednostek nie prowadzi w sposób konieczny do korzyści dla wydziału, na którym się one znajdują, jednak wskazuje na prawdopodobną korzyśś;

- $\mathrm{S}(82 / 76)=3, \mathrm{~S}(83 / 76)=3$ oraz $\mathrm{S}(84 / 76)=3$, ponieważ nie jest ani wskazane w analizowanym tekście ani jasne dla nie posiadającego rozległej wiedzy o kontekście odbiorcy, w jaki sposób zmiany te miałyby przynieść korzyść WN;

- $\mathrm{S}(85 / 76)=4$, ponieważ zwiększenie równowagi $\mathrm{z}$ dużym prawdopodobieństwem przynosi korzyść jednostce, w której równowaga ta zostaje zwiększona;

- $\mathrm{S}(86 / 76)=4$ oraz $\mathrm{S}(87 / 76)=4$, ponieważ zależność ta ma charakter oceny, do której twórca argumentacji ma jak się wydaje znaczące kompetencje.

Po dokonaniu obliczeń zgodnie z przyjętym schematem, otrzymujemy $\mathrm{A}(80)=4, \mathrm{~A}(85)=4$, co z kolei prowadzi do oceny stopnia akceptowalności ostatecznej tezy jako $\mathbf{A ( 7 6 ) = 4}$.

Ostatni $\mathrm{z}$ bardziej złożonych elementów analizowanej subargumentacji, stanowią twierdzenia przytoczone dla poparcia tezy (88), analiza których doprowadziła do rozpoznania następującej struktury: 


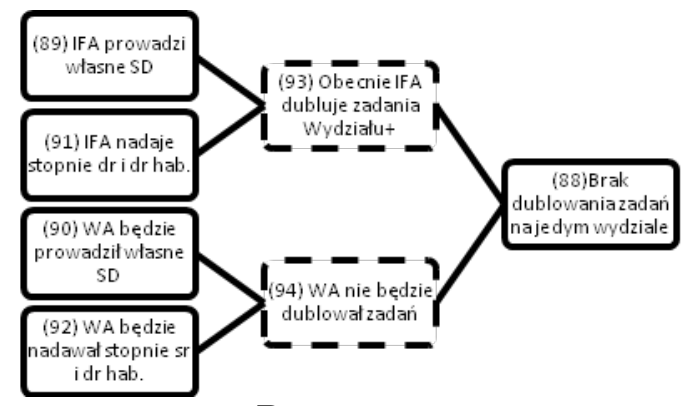

Rys. 5.4.3.

Dwóm pierwszym z nieuzasadnianych dalej przesłanek: (89) i (91) przypiszemy stopień akceptowalności 5 , gdyż wskazują one na fakty podlegające sprawdzeniu, dla pozostałych dwóch $\mathrm{A}(90)=4$ i $\mathrm{A}(92)=4$, gdyż jako dotyczące przyszłości nie mogą zostać uznane za pewne, jednak dotychczasowa działalność IFA wskazuje na duże prawdopodobieństwo ich zajścia. Jeśli chodzi o przejścia inferencyjne: $\mathrm{S}(89 / 93)=5$ oraz $\mathrm{S}(91 / 93)=5$, jest bowiem jednoznacznie pewne, że wykonywanie takich działań przez instytut prowadzi do dublowania zadań wydziału. Również S(90/94) $=5 \mathrm{i}$ $\mathrm{S}(92 / 94)=5$, ponieważ wykonywanie tych zadań przez Wydział nie dubluje zadań. Także $\mathrm{S}(93+94 / 88)=5$, ponieważ (88) wynika jednoznacznie $\mathrm{z}$ szeregowej argumentacji (93) +(94). W sumie otrzymujemy więc $\mathbf{A}(\mathbf{8 8})=\mathbf{4}$.

Po przeprowadzeniu analizy bardziej rozbudowanych fragmentów argumentacji dla tezy (5), możemy ocenić ostateczny stopień jej akceptowalności. 
dr Victoria Kamasa: Struktura argumentacji we wniosku formalnym...

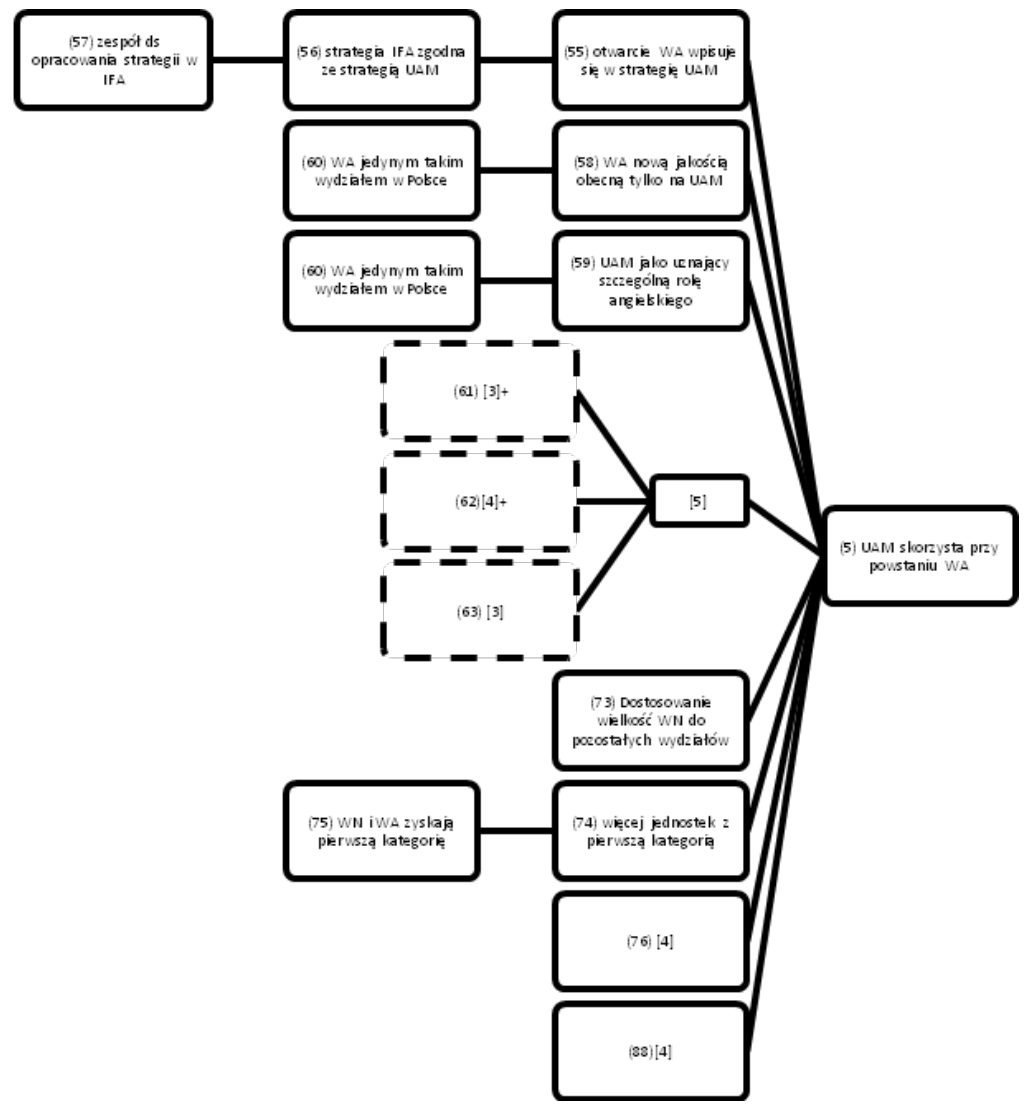

Rys. 5.4 .4

Dla składowych, wcześniej niezanalizowanych argumentacji przyjmiemy co następuje:

- $\mathrm{A}(57)=5$, ponieważ jest to fakt podlegający weryfikacji, $\mathrm{A}(57 / 56)=4$, ponieważ samo istnienie zespołu ds. strategii nie gwarantuje zgodności obu strategii, jednak znacząco ją uprawdopodabnia (w efekcie otrzymujemy $\mathrm{A}(56)=4), \mathrm{S}(56 / 55)=3$, ponieważ istnienie $\mathrm{w}$ IFA strategii zgodnej ze strategią UAM zasadniczo nie ma związku z faktem, że powołanie WA wpisuje się w strategię UAM (w efekcie $\mathrm{A}(55)=3), \quad \mathrm{S}(55 / 5)=5$, ponieważ zgodność jakiegoś działania ze strategią danej instytucji jednoznacznie wskazuje na korzyść tego działania dla tej instytucji. W efekcie $\mathrm{z}$ tej subargumentacji otrzymujemy $\mathbf{A}(\mathbf{5})=\mathbf{3}$

- $\mathrm{A}(60)=5$ ze względu na odniesienie do weryfikowalnych faktów, $\mathrm{S}(60 / 58)=5$, ponieważ posiadanie czegoś jedynego w kraju z pewnością jest świadectwem nowej jakości (w efekcie $\mathrm{A}(58)=5$ ), $\mathrm{S}(58 / 5)=4$, ponieważ obecność nowej jakości na UAM jest z dużym prawdopodobieństwem dla niego korzystna. W efekcie, dla tego fragmentu $\mathbf{A ( 5 )}=\mathbf{4}$.

- $\mathrm{S}(60 / 59)=4$, ponieważ stworzenie jedynego w Polsce Wydziału Anglistyki faktycznie $\mathrm{z}$ dużym prawdopodobieństwem może wskazywać na przypisywanie szczególnej roli językowi angielskiemu 
(w efekcie: $S(59)=4), \quad S(59 / 5)=3$, ponieważ związek między uznaniem wyjątkowej roli angielskiego a korzyściami płynącymi z takiego wizerunku dla UAM wydaje się niejasny. W efekcie, dla tego fragmentu $\mathbf{A ( 5 )}=\mathbf{3}$.

- $\mathrm{A}(73)=5$, ponieważ jest to fakt weryfikowalny, zaś $\mathrm{A}(73 / 5)=4$, ponieważ posiadanie wszystkich wydziałów $\mathrm{w}$ zbliżonych rozmiarach wydaje się $\mathrm{z}$ dość dużym prawdopodobieństwem przynosić korzyść UAM.

- $\mathrm{A}(75)=4$, gdyż na taką ocenę wskazuje sama autorka tekstu, $\mathrm{S}(75 / 74)=5$, ponieważ przejście ma charakter dedukcyjny (w efekcie $\mathrm{A}(74)=4)$, zaś $\mathrm{S}(74 / 5)=5$, jako że wzrost liczby jednostek z pierwszą kategorią przynosi jednoznaczną korzyść UAM. W efekcie, dla tego fragmentu $\mathbf{A ( 5 )}=\mathbf{4}$.

Po uwzględnieniu akceptowalności wszystkich twierdzeń bezpośrednio wspierających (5), siły inferencji między nimi a (5) oraz w większości

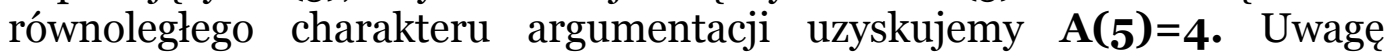
zwraca jednak fakt, że trzy spośród przedstawionych argumentów równoległych uzyskały ostateczną ocenę poniżej poziomu akceptowalności postulowanego przez Tokarza (Tokarz, 2006).

\subsection{Ocena stopnia akceptowalności dowodzonej tezy}

Przypomnijmy, że w wyniku przeprowadzonej analizy uzyskaliśmy następującą strukturę argumentacji głównej tezy oraz następujące oceny akceptowalności wspierających ją bezpośrednio przesłanek:

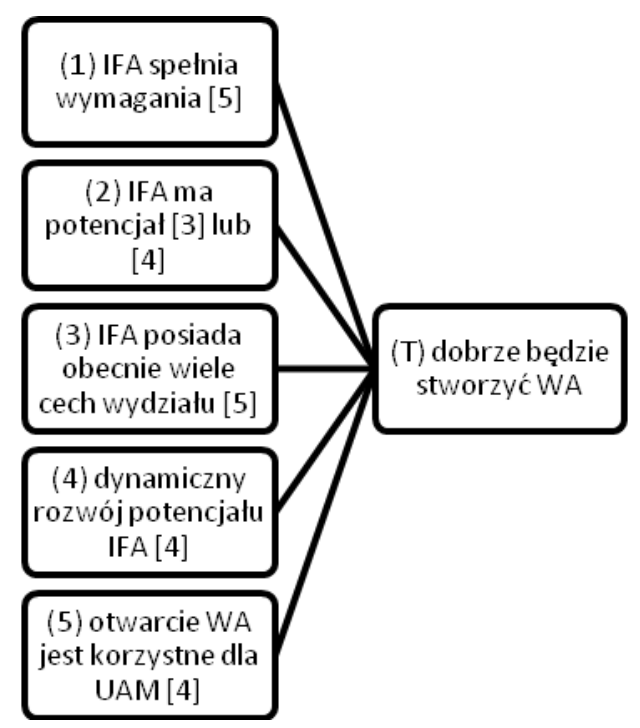

Rys.5.5.

Argumentacja ta zawiera jedną przesłankę (3), której stopień akceptowalności nie został wcześniej zanalizowany. Przyznanie jej stopnia akceptowalności 5 wydaje się uzasadnione jej odniesieniem do stanu 
faktycznego, który podlega weryfikacji. Bardziej złożoną kwestię wydaje się stanowić siła poszczególnych inferencji. I tak kolejno:

- $\mathrm{S}(1 / \mathrm{T})=3$, ponieważ (1) stanowi przekonujący dowód na to, że IFA spełnia wymagania stawiane wydziałom, co jednak w żaden sposób nie dowodzi, że otwarcie WA jest czymś dobrym. Możemy wskazać jak się wydaje wiele rozmaitych jednostek spełniających pewne wymagania, co jednak nie prowadzi do tego, że należy uczynić to, czego wspomniane wymagania dotyczą. Możemy posłużyć się tu przykładem mężczyzny, który spełnia wszystkie wymagania, by zostać żołnierzem misji pokojowej w Iraku, co jednak bynajmniej nie oznacza, że dobrze, by takim żołnierzem został.

- $\mathrm{S}(2 / \mathrm{T})=4$, jeśli przyjmiemy założenie, że jeśli instytut ma potencjał, to należy przekształcić go w wydział. Bez przyjęcia takiego założenia teza ta staje się irrelewantna dla twierdzenia, którego dotyczy, z siłą inferencji $\mathrm{S}(2 / \mathrm{T})=3$.

- $S(3 / T)=3$ przy argumentacji podobnej do tej przedstawionej dla $\mathrm{S}(1 / \mathrm{T})$.

- $\mathrm{S}(4 / \mathrm{T})=4$, podobnie jak w przypadku $\mathrm{S}(2 / \mathrm{T})$ wyłącznie po przyjęciu założenia, że instytuty o dynamicznie rozwijajacym się potencjale powinny być przekształcane w wydziały. Bez takiego założenia otrzymujemy, podobnie jak w poprzednim przypadku $\mathrm{S}(4 / \mathrm{T})=3$.

- $\mathrm{S}(5 / \mathrm{T})=4$, bowiem $\mathrm{z}$ dużym prawdopodobieństwem przyjąc możemy, że UAM powinien podejmować działania, które przynoszą mu korzyść.

Po dokonaniu obliczeń otrzymujemy ostatecznie $\mathbf{A ( T ) = 4}$, a zatem przytoczona argumentacja prowadzi do uznania postulowanej tezy. Warto jednak jak się wydaje zwrócić uwagę, że ten stopień akceptowalności uzyskiwany jest bezspornie jedynie na podstawie jednego $\mathrm{z}$ pięciu przedstawionych przez autorkę wniosku argumentów szeregowych. Dwa z pozostałych argumentów również prowadzą do stopnia akceptowalności tezy 4, jeśli zgodzimy się z założeniami milcząco przyjmowanymi przez autorkę, dwa zaś wydają się irrelewantne dla postulowanej tezy.

\section{Podsumowanie}

Przeprowadzona analiza pozwoliła zarówno na zidentyfikowanie struktury badanej argumentacji, jak i na ocenę akceptowalności tezy na podstawie przedstawionych przesłanek.

Jeśli chodzi o strukturę argumentacji uwagę mogą zwracać następujące kwestie:

- Znacząca przewaga argumentacji równoległej - w całej argumentacji wyróżniono jedynie 4 argumenty szeregowe. Fakt ten wydaje się tym bardziej interesujący, że w tekście odnaleźć możemy sformułowania, które mogłyby wskazywać na większą liczbę argumentów szeregowych, jak na przykład wspomniane już powyżej: kierując się zasadą otwartości z jednoczesnym dbaniem o najwyższajakość na światowym poziomie (U). 
- Tendencję, którą możemy określić jako ekonomizację wysiłku argumentacyjnego, polegającą na wykorzystaniu tego samego, raz wymienianego faktu, jako przesłanki dla kilku różnych twierdzeń, np. twierdzenie (7) w argumentacji dla (5) lub twierdzenie (81) w argumentacji dla również dla (5).

- Znaczące rozbudowanie argumentacji dla poszczególnych subtez wspierających tezę główną mające w większości charakter równoległej i bezpośredniej argumentacji. Taki sposób argumentacji może prowadzić do powstawania tak zwanego efektu kumulacyjnego, czyli sytuacji, w której wszystkie przesłanki razem wspieraja wniosek nieco silniej niż nawet najbardziej przekonywajaca $z$ nich wzięta $w$ izolacji od pozostatych (Tokarz, 2006, str. 136), a także częściowo zabezpiecza argumentację przed konsekwencjami wynikającymi z niezaakceptowania poszczególnych przesłanek bądź niskiej oceny przejść inferencyjnych.

Ocena argumentacji stanowi zadanie znacznie trudniejsze dla badacza, gdyż w jak się wydaje większym stopniu opiera się na jego intuicji badawczej a także dogłębnej znajomości szerokiego kontekstu, w którym argumentacja jest prowadzona. Dlatego też warta ponownego podkreślenia jest wspomniana już na początku ostrożność dotycząca zasadności tych ocen.

W tej analizie staraliśmy się w jak najmniejszym stopniu korzystać $\mathrm{z}$ wiedzy o kontekście, a odnosić się głównie do informacji zawartych w tekście. Przy zaproponowanych powyżej ocenach uwagę zwraca z jednej strony wysoki stopień akceptowalności przesłanek (zaledwie $3 \mathrm{z} 62$ nie uzasadnianych dalej twierdzeń oceniliśmy poniżej stopnia akceptowalności), z drugiej zaś stosunkowo częsta nieistotność przesłanek ze względu na tezę, dla której stanowią uzasadnienie (z takim przypadkiem mieliśmy do czynienia 24 razy na w sumie 78 przejść inferencyjnych, z czego dwa dotyczyły związku między dowodzoną tezą a bezpośrednimi przesłankami). Na uwagę zasługuje również silnie normatywny charakter niektórych uzasadnień, a więc przypadek, w którym argumentację możemy uznać za przekonującą jedynie jeśli zgadzamy się z normami implicite zakładanymi przez autorkę, a więc np. rozumieniem pojęcia potencjału naukowego.

Pytanie o reprezentatywność badanego tekstu dla wniosków formalnych zawierających argumentację, a więc innymi słowy o to, czy przedstawione tu cechy są $\mathrm{w}$ jakiejś części wspólne takim wnioskom, pozostaje oczywiście otwarte i dla znalezienia odpowiedzi na nie wymagałoby analizy większej liczby wniosków formalnych i ich porównania. 
dr Victoria Kamasa: Struktura argumentacji we wniosku formalnym...

\section{Bibliografia}

Blair, J. A. (1992). Everyday Argumentation from Informal Logic Perspective. In W. L. Benoit, D. Hample, \& P. J. Benoit, Readings in argumentation. (pp. 357378). New York: Fortis Publications.

Govier, T. (2010). A Practical Study of Argument. Belmont: Cengage Learning.

Govier, T. (1987). Problems in argument analysis and evaluation. Dordrecht: Fortis Publications Holland.

Searle, J. R. (1987). Czynności mowy. Rozważania z filozofii języka. Warszawa: Instytut Wydawniczy Pax.

Szymanek, K. (2001). Sztuka argumentacji: stownik terminologiczny. Warszawa: Wydawnictwo Naukowe PWN.

Tokarz, M. (2006). Argumentacja. Perswazja. Manipulacja. Gdańsk: Gdańskie Wydawnictwo Psychologiczne. 